\title{
Remission in systemic lupus erythematosus: testing different definitions in a large multicentre cohort
}

Francesca Saccon, ${ }^{1}$ Margherita Zen, ${ }^{1}$ Mariele Gatto, ${ }^{1}$ Domenico Paolo Emanuele Margiotta, ${ }^{2}$ Antonella Afeltra, ${ }^{2}$ Fulvia Ceccarelli ${ }^{\circ},{ }^{3}$ Fabrizio Conti, ${ }^{4}$ Alessandra Bortoluzzi, ${ }^{5}$ Marcello Govoni, ${ }^{5}$ Giulia Frontini, ${ }^{6}$ Gabriella Moroni 이, ${ }^{6}$ Francesca Dall'Ara, ${ }^{7}$ Angela Tincani, ${ }^{7}$ Viola Signorini, ${ }^{8}$ Marta Mosca, ${ }^{8}$ Anna Chiara Frigo, ${ }^{9}$ Luca laccarino, ${ }^{1}$ Andrea Doria (1) ${ }^{1}$

Handling editor Josef $S$ Smolen

- Additional material is published online only. To view please visit the journal online (http://dx.doi.org/10.1136/ annrheumdis-2020-217070).

For numbered affiliations see end of article.

Correspondence to Professor Andrea Doria, Department of Medicine, Division of Rheumatology, University of Padua, Padova 35128, Italy; adoria@unipd.it

Received 30 January 2020 Revised 13 March 2020 Accepted 1 April 2020 Published Online First 22 April 2020
Check for updates

(C) Author(s) (or their employer(s)) 2020. No commercial re-use. See rights and permissions. Published by BMJ.

\section{To cite: Saccon $F$,}

Zen M, Gatto M

et al. Ann Rheum Dis

2020;79:943-950.

\section{ABSTRACT}

Objectives Remission in systemic lupus erythematosus (SLE) is defined through a combination of 'clinical SLE Disease Activity Index (cSLEDAI)=0', 'physician's global assessment (PGA) $<0.5^{\prime}$ and 'prednisone (PDN) $\leq 5 \mathrm{mg}$ / day'. We investigated the performance of these items, alone or in combination, in defining remission and in predicting SLICC/ACR Damage Index.

Methods We tested seven potential definitions of remission in SLE patients followed-up for $\geq 5$ years: PDN $\leq 5 \mathrm{mg} /$ day; PGA $<0.5 ;$ cSLEDAl $=0 ;$ PGA $<0.5$ plus PDN $\leq 5 \mathrm{mg} /$ day; cSLEDAl $=0$ plus PGA $<0.5$; cSLEDAl $=0$ plus PDN $\leq 5 \mathrm{mg} /$ day; cSLEDAl $=0$ plus PDN $\leq 5 \mathrm{mg} /$ day plus $P G A<0.5$. The effect of these definitions on damage was evaluated by Poisson regression analysis; the best performance was identified as the lowest Akaike and Bayesian information criterion (AIC and BIC). Positive and negative predictive values in identifying no damage increase were calculated.

Results We included 646 patients (mean \pm SD disease duration $9.2 \pm 6.9$ years). At multivariate analysis, $\geq 2$ consecutive year remission according to all definitions protected against damage $(\mathrm{OR}, 95 \% \mathrm{Cl}$ : PGA $<0.5$ $0.631,0.444$ to $0.896 ; \mathrm{CSLEDAI}=00.531,0.371$ to 0.759; PGA <0.5 plus PDN $\leq 5 \mathrm{mg} /$ day $0.554,0.381$ to 0.805; CSLEDAI $=0$ plus PGA $<0.50 .574,0.400$ to 0.826 ; cSLEDAl=0 plus PDN $\leq 5 \mathrm{mg} /$ day $0.543,0.376$ to 0.785 cSLEDAl $=0$ plus PDN $\leq 5 \mathrm{mg} /$ day plus $\mathrm{PGA}<0.50 .532$, 0.363 to $0.781, p<0.01$ for all), except PDN $\leq 5 \mathrm{mg} /$ day, which required four consecutive years (OR $0.534,95 \% \mathrm{Cl}$ 0.325 to $0.877, p=0.013)$. Positive and negative predictive values were similar; however, $C S L E D A I=0$ showed the best performance (AIC 1082.90, BIC 1109.72, p<0.0001). Adding PGA $<0.5$ and/or PDN $\leq 5 \mathrm{mg} /$ day to $C S L E D A I=0$ decreased remission duration (-1.8 and -1.5 year/patient, respectively) without increasing $\mathrm{CSLEDAI}=0$ performance in predicting damage accrual.

Conclusions $C S L E D A I=0$ is the most attainable definition of remission, while displaying the best performance in predicting damage progression in the short-to-mid-term follow-up.

\section{INTRODUCTION}

Remission is the most desirable target in the management of systemic lupus erythematosus (SLE), as it leads to a significant improvement across several disease outcome measures (death, organ damage, disease flare-up and health-related quality of life

\section{Key messages}

What is already known about this subject?

- Remission is the most desirable target in systemic lupus erythematosus (SLE); however, a universally accepted definition is still missing.

What does this study add?

- A simple definition of remission based on clinical SLE Disease Activity Index (SLEDAI) $=0$ is easy-to-achieve and protective against damage.

- Adding Physician Global Assessment $(<0.5)$ to clinical SLEDAI $=0$ decreases the proportion of remitted patients without increasing the performance of clinical SLEDAI in predicting damage accrual.

How might this impact on clinical practice or future developments?

- Clinical SLEDAI=0 could serve as a manageable and meaningful outcome in SLE trials and treatto-target strategy.

$($ HRQoL $))^{1-9}$; however, a universally accepted definition of remission combining evidence-based medicine and expert opinion is still missing. ${ }^{3} 1011$ The Definitions Of Remission In SLE (DORIS) international task force defined remission as a sustained state without any symptoms and signs of SLE, assessing disease activity according to the clinical SLE Disease Activity Index 2000 (cSLEDAI), ${ }^{10}$ which does not take into account serology, ${ }^{12}$ and evaluating the global patient status by Physician Global Assessment (PGA). Addition of PGA was meant to reflect the overall clinician-based evaluation, thereby filling the gaps of cSLEDAI and being also suggested to reflect the patient's perspective. ${ }^{10}$

Since moderate-to-high glucocorticoid dosages contribute to damage accrual in the long term, a prednisone (PDN) dose (or equivalent) $\leq 5 \mathrm{mg} /$ day was included in the validated definitions of remission. 3101314

It should be noted that no clear agreement was reached so far in defining durability in time of any definition of remission, which remains a research priority.

To our knowledge, no head-to-head comparisons were made on the impact of each item or combination 
of items included in the definitions of remission proposed by the DORIS task force (ie, cSLEDAI $=0$, PGA $<0.5$, PDN $\leq 5 \mathrm{mg} /$ day) on disease outcomes in a clinical practice setting. Our aim was to compare the prevalence and duration of different potential definitions of remissions and to evaluate their effect on organ damage in a large, closely monitored cohort of patients with SLE.

\section{PATIENTS AND METHODS}

\section{Data source}

We carried out a multicentre study enrolling patients with SLE recruited in seven referral lupus centres in Italy: University of Padova, Campus Bio-Medico University (Rome), Sapienza University (Rome), University of Brescia, University Hospital S. Anna (Ferrara), Fondazione Ca' Granda IRCCS Ospedale Maggiore Policlinico (Milano) and University of Pisa. All patients provided an informed consent before the inclusion in the study.

Patients with SLE were enrolled in the study according to the fulfilment of all the following criteria: (1) $\geq 4$ revised American College of Rheumatology (ACR) Classification Criteria for SLE; (2) SLE diagnosis between 1990 and 2013; (3) active disease, that is, at least one clinical manifestation scored in the SLEDAI-2K, or remission lasting no more than 12 months at study entry; (4) at least five consecutive years of follow-up between January 2009 and September 2018; (5) at least three visits per year, no more than 5 months apart. We analysed a period of 5-year for all patients. Data regarding disease manifestations, autoantibody profile, medical history and organ damage were recorded since SLE diagnosis. The cumulative PDN dose taken before baseline was calculated. Clinical and laboratory findings were collected at each visit.

\section{Study variables}

At each visit SLE activity was measured by SLEDAI-2K and PGA (scale 0-3). Flares were defined according to SELENA-SLEDAI flare index. ${ }^{15}$ Organ damage was assessed by Systemic Lupus International Collaborating Clinics/ACR Damage Index (SDI), which was calculated at baseline and annually thereafter. SDI increase was defined as the difference between SDI at the end and at the beginning of the 5-year follow-up. Damage was categorised as related to or independent from glucocorticoids, as defined by Gladman et $\mathrm{al}^{16}$

We considered the three major items included in the DORIS definition of 'remission on therapy': (1) PGA <0.5; (2) cSLEDAI $=0$; (3) $\mathrm{PDN} \leq 5 \mathrm{mg} /$ day (or equivalent) daily intake. We also tested their combinations: (4) PGA $<0.5$ plus PDN $\leq 5 \mathrm{mg} /$ day; (5) cSLEDAI $=0$ plus $\mathrm{PGA}<0.5 ;$ (6) $\mathrm{cSLEDAI}=0$ plus $\mathrm{PDN} \leq 5 \mathrm{mg} /$ day; (7) $\mathrm{cSLEDAI}=0$ plus $\mathrm{PDN} \leq 5 \mathrm{mg} /$ day plus PGA $<0.5 .^{10}$ All seven potential definitions are presented in table 1. For composite definitions, remission was considered as achieved when the two or three items were concomitantly met. One consecutive year was considered the shortest duration of remission for a clinically meaningful definition. In patients with a relapsing-remitting disease, only the longest period of remission was considered in the analysis.

For all definitions, concomitant lupus medications (antimalarials and/or immunosuppressive drugs and/or biologics) were allowed if on a stable dose. Haemolytic anaemia, myelitis and gastrointestinal lupus involvement prevented the fulfilment of all remission definitions.

We also performed a separate analysis, where the cumulative time spent in remission was evaluated and expressed as proportion of the follow-up in remission, that is, $<25 \%, 25 \%-49 \%$, $50 \%-74 \%, 75 \%-99 \%$ and $100 \%$.

\section{Statistical analysis}

T-test was used to compare continuous data with a parametric distribution. Comparison of categorical variables were performed using $\chi^{2}$ test (Fisher's exact test if necessary). Remission definitions were considered as six-levels categorical variables according to duration ( $0,1,2,3,4$ and 5 consecutive years). Cohen's kappa coefficient $(\kappa)$ and $95 \%$ CI were used to assess agreement among remission definitions. The patient's demographic and clinical characteristics and remission definitions were tested as predictors of damage accrual by univariate Poisson regression analysis. Those variables with $\mathrm{p}<0.2$ were considered in a multivariate Poisson regression analysis. ORs were estimated with 95\% CI. The goodness-of-fit was assessed using Akaike information criterion (AIC) and Bayesian information criterion (BIC): the best performance in predicting damage accrual was identified by the lowest AIC and BIC. Analyses were performed by SAS V.9.4 (SAS Institute) and SPSS (V.25 for Windows), and $\mathrm{p}<0.05$ was considered statistically significant.

This research was done without patient involvement and patients were not invited to comment on the study design or to develop patient outcomes.

\section{RESULTS}

Six hundred and forty-six consecutive lupus patients fulfilled inclusion criteria: 621 (96.1\%) Caucasian, 585 (90.6\%) female, mean \pm SD age at baseline $40.6 \pm 12.1$ years, disease duration $9.2 \pm 6.9$ years. At baseline, 545 patients $(84.4 \%)$ were taking PDN, 460 (71.2\%) antimalarials and 316 (48.8\%) immunosuppressants. Demographic and clinical characteristics of patients are reported in table 2 .

Table 1 Definitions of remission according to clinical, serological and therapeutic status allowed

\begin{tabular}{|c|c|c|c|c|c|}
\hline & \multicolumn{3}{|c|}{ Disease activity } & \multicolumn{2}{|l|}{ Treatment } \\
\hline & \multicolumn{2}{|l|}{ SLEDAI-2K } & \multirow[b]{2}{*}{ PGA } & \multirow[b]{2}{*}{ PDN } & \multirow{2}{*}{$\begin{array}{l}\text { Antimalarials, biologics } \\
\text { immunosuppressants* }\end{array}$} \\
\hline & Clinical & Serological & & & \\
\hline $\mathrm{PDN} \leq 5 \mathrm{mg} / \mathrm{day}$ & Regardless & Regardless & Regardless & $\leq 5 \mathrm{mg} /$ day & Regardless \\
\hline$P G A<0.5$ & Regardless & Regardless & $<0.5$ & Regardless & Regardless \\
\hline$C S L E D A I=0$ & 0 & Regardless & Regardless & Regardless & Regardless \\
\hline $\mathrm{PDN} \leq 5 \mathrm{mg} /$ day plus $\mathrm{PGA}<0.5$ & Regardless & Regardless & $<0.5$ & $\leq 5 \mathrm{mg} /$ day & Regardless \\
\hline cSLEDAl $=0$ plus $P G A<0.5$ & 0 & Regardless & $<0.5$ & Regardless & Regardless \\
\hline cSLEDAl $=0$ plus $P D N \leq 5 \mathrm{mg} /$ day & 0 & Regardless & Regardless & $\leq 5 \mathrm{mg} /$ day & Regardless \\
\hline cSLEDAI $=0$ plus $P D N \leq 5 \mathrm{mg} /$ day plus $\mathrm{PGA}<0.5$ & 0 & Regardless & $<0.5$ & $\leq 5 \mathrm{mg} /$ day & Regardless \\
\hline
\end{tabular}

*Stable well-tolerated doses.

CSLEDAI, clinical systemic lupus erythematosus Disease Activity Index 2000; PDN, prednisone equivalent; PGA, physician global assessment. 
Table 2 Demographic and clinical characteristics of lupus patients in the whole cohort and in patients with cSLEDAl=0 for at least 1 year

\begin{tabular}{|c|c|c|c|c|c|}
\hline & & cSLEDAI $=0$ & t 1 year & & \\
\hline & $\begin{array}{l}\text { Whole cohort } \\
646(100)\end{array}$ & $\begin{array}{l}\text { Overall } \\
548(84.8)\end{array}$ & $\begin{array}{l}\text { PGA }<0.5 \\
\text { concordant with } \\
\text { cSLEDAI=0 } \\
353(64.4)\end{array}$ & $\begin{array}{l}\text { PGA }<0.5 \\
\text { discordant with } \\
\text { cSLEDAI=0 } 195 \\
(35.6)\end{array}$ & $P$ value \\
\hline Female & $585(90.6)$ & $502(77.8)$ & $324(64.5)$ & 178 (35.5) & ns \\
\hline Age at baseline, years & $40.6 \pm 12.1$ & $40.7 \pm 12.2$ & $39.8 \pm 12.3$ & $42.4 \pm 12.0$ & 0.015 \\
\hline SLE duration $\leq 2$ years & $159(24.6)$ & $139(21.5)$ & $107(77.0)$ & $52(37.4)$ & ns \\
\hline Disease duration, years & $9.2 \pm 6.7$ & $8.9 \pm 6.8$ & $9.1 \pm 6.8$ & $8.7 \pm 6.9$ & ns \\
\hline Damage & & & & & \\
\hline SDI baseline & $0.55 \pm 0.96$ & $0.52 \pm 0.94$ & $0.50 \pm 0.96$ & $0.55 \pm 0.91$ & ns \\
\hline SDI increase during FU & $0.43 \pm 0.74$ & $0.36 \pm 0.67$ & $0.35 \pm 0.68$ & $0.37 \pm 0.67$ & ns \\
\hline SDI increase during FU & $206(31.9)$ & $149(27.2)$ & $92(26.1)$ & $57(29.2)$ & ns \\
\hline $\mathrm{GC}$ related SDI & $88(13.6)$ & $69(12.6)$ & $40(11.3)$ & $29(14.9)$ & ns \\
\hline GC possibly related SDI & $43(6.7)$ & $33(6.0)$ & $21(5.9)$ & $12(6.2)$ & ns \\
\hline GC independent SDI & $101(15.6)$ & $64(11.7)$ & $43(12.2)$ & $21(10.8)$ & ns \\
\hline Lupus flare during FU & & & & & \\
\hline Muco-cutaneous & $243(37.6)$ & $189(34.5)$ & $93(26.3)$ & 44 (22.6) & ns \\
\hline Musculoskeletal & $249(38.5)$ & $213(38.9)$ & $97(27.5)$ & $70(35.9)$ & 0.040 \\
\hline Serositic & $45(7.0)$ & $37(6.8)$ & $22(6.2)$ & $6(3.1)$ & ns \\
\hline Neurological & $36(5.6)$ & $28(5.1)$ & $12(3.4)$ & $8(4.1)$ & ns \\
\hline Glomerulonephritis & $202(31.3)$ & $149(27.2)$ & $76(21.5)$ & $36(18.5)$ & ns \\
\hline Haematological & $166(25.7)$ & $138(25.2)$ & $81(22.9)$ & $39(20.0)$ & ns \\
\hline Therapy during follow-up & & & & & \\
\hline Cumulative PDN, grams & $11.25 \pm 14.55$ & $9.87 \pm 13.45$ & $8.64 \pm 11.40$ & $12.10 \pm 16.31$ & 0.004 \\
\hline Immunosuppressants & $316(48.9)$ & $250(45.6)$ & $150(42.5)$ & $100(51.3)$ & 0.048 \\
\hline Antimalarials & $460(71.2)$ & $394(71.9)$ & $248(70.3)$ & $146(74.9)$ & ns \\
\hline Belimumab & $48(7.4)$ & $32(4.9)$ & $19(59.4)$ & $13(40.6)$ & ns \\
\hline Previous treatments & & & & & \\
\hline Immunosuppressant ever & $381(59.0)$ & $306(55.8)$ & $199(56.4)$ & $107(54.9)$ & ns \\
\hline Mycophenolate Mofetil & $197(30.5)$ & $150(27.4)$ & $103(29.2)$ & $47(24.1)$ & ns \\
\hline Cyclophosphamide & $144(22.3)$ & $111(20.3)$ & $75(21.2)$ & $36(18.5)$ & ns \\
\hline Azathioprine & $200(31.0)$ & $158(28.8)$ & $105(29.7)$ & $53(27.2)$ & ns \\
\hline Cyclosporine A & $110(17.0)$ & $83(15.2)$ & $56(15.9)$ & $27(13.8)$ & ns \\
\hline Methotrexate & $90(13.9)$ & $67(12.2)$ & $32(9.1)$ & 35 (17.9) & 0.002 \\
\hline Antimalarials & $483(74.8)$ & $409(74.6)$ & $267(75.6)$ & $142(72.8)$ & ns \\
\hline Rituximab & $31(4.8)$ & $18(3.3)$ & $11(3.1)$ & $7(3.6)$ & ns \\
\hline Belimumab & $41(6.4)$ & $29(5.3)$ & $15(4.2)$ & $14(7.2)$ & ns \\
\hline IV $\lg$ & $28(4.3)$ & $19(3.5)$ & $10(2.8)$ & $9(4.6)$ & ns \\
\hline Plasmapheresis & $26(4.0)$ & $20(3.7)$ & $11(3.1)$ & $9(4.6)$ & ns \\
\hline Previous lupus manifestations, $\mathrm{e}$ & & & & & \\
\hline Muco-cutaneous & $412(63.8)$ & $342(62.4)$ & $214(60.6)$ & $128(65.6)$ & ns \\
\hline Musculoskeletal & $436(67.5)$ & $371(67.7)$ & $230(65.2)$ & $141(72.3)$ & ns \\
\hline Serosal & $125(19.4)$ & $98(17.9)$ & $65(18.4)$ & $33(16.9)$ & ns \\
\hline Neurological & $103(15.9)$ & $82(15.0)$ & $39(11.0)$ & $43(22.1)$ & 0.001 \\
\hline Glomerulonephritis & $262(40.6)$ & $206(37.6)$ & $148(41.9)$ & $58(29.7)$ & 0.005 \\
\hline Haematological & $245(37.9)$ & $211(38.5)$ & $139(39.4)$ & $72(36.9)$ & ns \\
\hline Anti-dsDNA antibodies & $490(75.9)$ & $412(75.2)$ & $259(73.4)$ & $153(78.5)$ & ns \\
\hline Anti-SSA/SSB antibodies & $275(42.7)$ & $229(41.9)$ & $145(41.2)$ & $84(43.3)$ & ns \\
\hline Anti-U1RNP antibodies & $135(20.9)$ & $107(19.6)$ & $76(21.6)$ & $31(15.9)$ & ns \\
\hline Anti-Sm antibodies & $93(14.4)$ & $74(13.5)$ & $45(12.7)$ & $29(14.9)$ & ns \\
\hline Antiphospholipid antibodies & $258(39.9)$ & $220(40.1)$ & $140(39.7)$ & $80(41.0)$ & ns \\
\hline Antiphospholipid syndrome & $94(14.6)$ & $80(14.6)$ & $51(14.4)$ & $29(14.9)$ & ns \\
\hline
\end{tabular}

Data are reported as number (\%) or mean \pm SD.

anti-dsDNA, anti double-stranded DNA; anti-U1RNP, anti-(U1) ribonucleoprotein; cSLEDAl, clinical SLE Disease Activity Index 2000; FU, follow-up; GC, glucocorticoids; IV Ig, intravenous immunoglobulines; ns, not significant; PDN, prednisone; PGA, physician global assessment; SDI, Systemic Lupus International Collaborating Clinics/American College of Rheumatology Damage Index; SLE, systemic lupus erythematosus. 
Table 3 Number (\%) of patients in remission according to different definitions

\begin{tabular}{|c|c|c|c|c|c|c|c|}
\hline & $\mathrm{PDN} \leq 5 \mathrm{mg} /$ day & PGA $<0.5$ & cSLEDAI $=0$ & $\begin{array}{l}\mathrm{PGA}<0.5 \text { plus } \\
\mathrm{PDN} \leq 5 \mathrm{mg} / \text { day }\end{array}$ & $\begin{array}{l}\text { CSLEDAI }=0 \text { plus } \\
\text { PGA }<0.5\end{array}$ & $\begin{array}{l}\text { cSLEDAI }=0 \text { plus } \\
\text { PDN } \leq 5 \mathrm{mg} / \text { day }\end{array}$ & $\begin{array}{l}\text { cSLEDAI }=0 \text { plus } \\
\text { PDN } \leq 5 \mathrm{mg} / \text { day plus } \mathrm{PGA}<0.5\end{array}$ \\
\hline Unremitted patients & $73(11.3)$ & $164(25.4)$ & $98(15.2)$ & $194(30.0)$ & $170(26.3)$ & $147(22.8)$ & $199(30.8)$ \\
\hline At least 1 year remission & $573(88.7)$ & $482(74.6)$ & $548(84.8)$ & $452(70.0)$ & $476(73.7)$ & $499(77.2)$ & 447 (69.2) \\
\hline At least 2 years remission & $512(79.3)$ & $377(58.4)$ & $456(70.6)$ & $352(54.5)$ & $369(57.1)$ & $409(63.2)$ & $346(53.6)$ \\
\hline At least 3 years remission & $425(65.8)$ & $264(40.9)$ & $327(50.6)$ & $248(38.4)$ & $254(39.3)$ & $294(45.5)$ & $243(37.6)$ \\
\hline At least 4 years remission & $345(53.4)$ & $173(26.8)$ & $250(38.7)$ & $166(25.7)$ & $167(25.9)$ & $220(34.1)$ & $161(24.9)$ \\
\hline 5 years remission & $222(34.4)$ & $84(13.0)$ & $119(18.4)$ & $81(12.5)$ & $82(12.7)$ & $107(16.6)$ & $80(12.4)$ \\
\hline
\end{tabular}

cSLEDAl, clinical SLE Disease Activity Index 2000; PDN, prednisone equivalent; PGA, physician global assessment; SLE, systemic lupus erythematosus.

\section{Prevalence of remission using different definitions}

According to the seven different definitions, remission lasting at least 1 year was achieved by a proportion of patients ranging between $69.2 \%$ and $88.7 \%$ and two consecutive year remission by more than $50 \%$ of patients (table 3 ).

\section{Overlapping and agreement among different definitions}

The overlapping of the three major items included in the DORIS definitions of remission (cSLEDAI $=0$, PGA $<0.5$, PDN $\leq 5 \mathrm{mg} /$ day) is shown in figure 1.

The agreement was poor between $\mathrm{PDN} \leq 5 \mathrm{mg} / \mathrm{day}$ and other definitions except for cSLEDAI $=0$ plus $P D N \leq 5 \mathrm{mg} /$ day $(\kappa=0.622)$ (online supplementary table S1).

The agreement between $\mathrm{cSLEDAI}=0$ and PGA $<0.5$ was good $(\kappa=0.697)$. Patients with PGA $<0.5$ usually had a concomitant $\mathrm{cSLEDAI}=0$, but not vice versa.

When $\mathrm{PDN} \leq 5 \mathrm{mg} /$ day was added to $\mathrm{PGA}<0.5$ or $\mathrm{cSLEDAI}=0$ there was a good agreement with PGA $<0.5$ alone $(\kappa=0.921)$ or $\mathrm{cSLEDAI}=0$ alone $(\kappa=0.837)$, respectively, since patients in remission according to $\mathrm{cSLEDAI}=0$ or $\mathrm{PGA}<0.5$ were often taking a dosage of PDN $\leq 5 \mathrm{mg} /$ day.

When PGA $<0.5$ was added to $c S L E D A I=0$ and/or PDN $\leq 5 \mathrm{mg}$ /day the prevalence of unremitted patients increased. As it was very uncommon that a patient fulfilled PGA $<0.5$ and $\mathrm{PDN} \leq 5 \mathrm{mg} /$ day, but not cSLEDAI $=0$, a very high agreement was observed between PGA $<0.5$ plus $P D N \leq 5 \mathrm{mg} /$ day and cSLEDAI $=0$ plus $\mathrm{PDN} \leq 5 \mathrm{mg} /$ day plus $\mathrm{PGA}<0.5(\kappa=0.981)$.

\section{Comparison between $\mathrm{CSLEDAI}=0$ and $\mathrm{PGA}<0.5$}

The mean time spent in remission was significantly shorter when remission was defined according to PGA $<0.5$ compared with $\quad \mathrm{cSLEDAI}=0 \quad(2.1 \pm 1.7$ vs $2.63 \pm 1.7$ years, $\mathrm{p}<0.001)$.

A.

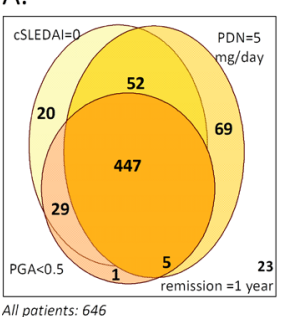

B.

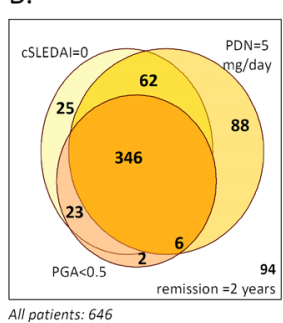

C.

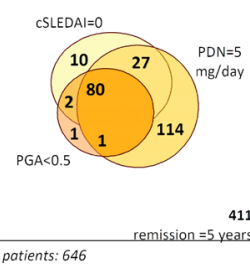

Figure 1 Venn diagram representing the number of patients fulfilling the three single major remission items (PGA $<0.5$; cSLEDAI=0; PDN $\leq 5 \mathrm{mg} /$ day) and their combination, during a 5 -year follow-up. (A) Patients achieving at least 1-year remission. (B) Patients with at least two consecutive years in remission. (C) Patients achieving prolonged remission (five consecutive years). cSLEDAI, clinical SLE Disease Activity Index 2000; PGA, physician global assessment; PDN, prednisoneequivalent; SLE, systemic lupus erythematosus.
cSLEDAI $=0$ was observed in 548/646 patients $(84.8 \%)$, while concomitant $\mathrm{cSLEDAI}=0$ and $\mathrm{PGA} \geq 0.5$ were observed in $195 / 548$ patients $(35.6 \%)$ (table 2 ), meaning a loss of remission of 1.8 year/patient when PGA $<0.5$ was added to $\mathrm{cSLEDAI}=0$.

To understand the reason why some patients had PGA $\geq 0.5$ despite $\mathrm{cSLEDAI}=0$, we compared patients who could not be defined as remitted with those showing no change in remission duration after adding PGA $<0.5$ to $\mathrm{CSLEDAI}=0$ (table 2). Among patients with $\mathrm{cSLEDAI}=0$, no difference in prevalence, extent or type of damage accrual was observed between those displaying PGA $<0.5$ or PGA $\geq 0.5$. Patients with $\mathrm{PGA} \geq 0.5$ despite $c S L E D A I=0$ had more frequently musculoskeletal activity/involvement and were more commonly treated with immunosuppressants and/or higher dose of glucocorticoids during follow-up; moreover, they had less frequently previous glomerulonephritis and more commonly previous neurological involvement compared with patients with PGA $<0.5$ plus cSLEDAI $=0$ (table 2).

Among patients with musculoskeletal activity, no significant difference was observed in the proportion of patients with PGA $\geq 0.5$ despite $\mathrm{cSLEDAI}=0$ in patients who developed Jaccoud-like arthropathy compared with the overall cohort, confirming that damage was not scored as activity.

Among 195 patients with PGA $\geq 0.5$ and $\mathrm{cSLEDAI}=0,126$ (64.6\%) were on PDN $\leq 5 \mathrm{mg} /$ day achieving $\mathrm{cSLEDAI}=0$ plus $\mathrm{PDN} \leq 5 \mathrm{mg} /$ day remission; $155 / 195(79.5 \%)$ were in lupus low disease activity state (LLDAS) according to Franklyn's definition (SLEDAI-2K $\leq 4$ and PGA $\leq 1$ and PDN $\leq 7.5 \mathrm{mg} /$ day). ${ }^{17}$ Forty patients did not fulfil LLDAS definition due to a PGA $>1$ $(\mathrm{n}=21)$ and/or PDN intake $>7.5 \mathrm{~g} /$ day $(\mathrm{n}=33)$.

\section{Patients with no residual disease activity (CSLEDAI $=0$ and/or PGA $<0.5$ ) on PDN > 5 mg/day}

When PDN $\leq 5 \mathrm{mg} /$ day was added to cSLEDAI $=0,112(17.3 \%)$ patients did not meet remission criteria. This may be due to a longer time needed for glucocorticoid tapering after resolution of the disease manifestations, leading to prolonged PDN intake $(>5 \mathrm{mg} /$ day) despite $\mathrm{cSLEDAI}=0$. Accordingly, the difference in the proportion of patients in $\mathrm{cSLEDAI}=0$ and $\mathrm{cSLEDAI}=0$ plus $\mathrm{PDN} \leq 5 \mathrm{mg} /$ day decreased over time, as the longer the remission duration the higher the probability of minimising/withdrawing PDN therapy.

Overall, these patients lost 1.5 year/patient in remission. Among them, patients with renal or serosal involvement lost 2 years/patient in remission, those with haematological manifestations 1.5 year/patient in remission, and patients with articular, cutaneous, constitutional involvement 1.3 year/patient in remission, suggesting that time to reduce $\mathrm{PDN} \leq 5 \mathrm{mg} /$ day after achieving $\mathrm{cSLEDAI}=0$ was different depending on the specific SLE manifestation. 
Table 4 ORs $(95 \% \mathrm{Cl})$ and goodness-of-fit of different definitions of remission in predicting damage accrual by Poisson regression*

\begin{tabular}{|c|c|c|c|c|c|c|c|}
\hline & $\mathrm{PDN} \leq 5 \mathrm{mg} /$ day & PGA $<0.5$ & cSLEDAI $=0$ & $\begin{array}{l}\text { PGA }<0.5 \text { plus PDN } \\
\leq 5 \mathrm{mg} / \text { day }\end{array}$ & $\begin{array}{l}\text { cSLEDAI }=0 \text { plus } \\
\text { PGA }<0.5\end{array}$ & $\begin{array}{l}\text { cSLEDAl }=0 \text { plus } \\
\text { PDN } \leq 5 \mathrm{mg} / \text { day }\end{array}$ & $\begin{array}{l}\text { cSLEDAI }=0 \text { plus } \\
\text { PGA }<0.5 \text { plus } P D N \\
\leq 5 \mathrm{mg} / \text { day }\end{array}$ \\
\hline $\begin{array}{l}\text { Five consecutive year } \\
\text { remission }\end{array}$ & $\begin{array}{l}0.620 \\
(0.430 \text { to } 0.894) \\
0.010\end{array}$ & $\begin{array}{l}0.377 \\
(0.293 \text { to } 0.595) \\
<0.0001\end{array}$ & $\begin{array}{l}0.382 \\
(0.260 \text { to } 0.561) \\
<0.0001\end{array}$ & $\begin{array}{l}0.363 \\
(0.227 \text { to } 0.581) \\
<0.0001\end{array}$ & $\begin{array}{l}0.397 \\
(0.251 \text { to } 0.626) \\
<0.0001\end{array}$ & $\begin{array}{l}0.411 \\
(0.275 \text { to } 0.614) \\
0.0001\end{array}$ & $\begin{array}{l}0.374 \\
(0.234 \text { to } 0.599) \\
<0.0001\end{array}$ \\
\hline $\begin{array}{l}\text { Four consecutive year } \\
\text { remission }\end{array}$ & $\begin{array}{l}0.391 \\
(0.245 \text { to } 0.625) \\
<0.0001\end{array}$ & $\begin{array}{l}0.226 \\
(0.130 \text { to } 0.394) \\
<0.0001\end{array}$ & $\begin{array}{l}0.173 \\
(0.105 \text { to } 0.286) \\
<0.0001\end{array}$ & $\begin{array}{l}0.294 \\
(0.177 \text { to } 0.487) \\
<0.0001\end{array}$ & $\begin{array}{l}0.243 \\
(0.140 \text { to } 0.424) \\
<0.0001\end{array}$ & $\begin{array}{l}0.251 \\
(0.155 \text { to } 0.405) \\
<0.0001\end{array}$ & $\begin{array}{l}0.296 \\
(0.176 \text { to } 0.496) \\
<0.0001\end{array}$ \\
\hline $\begin{array}{l}\text { Three consecutive year } \\
\text { remission }\end{array}$ & $\begin{array}{l}0.912 \\
(0.601 \text { to } 1.386) \\
0.668\end{array}$ & $\begin{array}{l}0.427 \\
(0.281 \text { to } 0.649) \\
<0.0001\end{array}$ & $\begin{array}{l}0.512 \\
(0.342 \text { to } 0.767) \\
0.0001\end{array}$ & $\begin{array}{l}0.430 \\
(0.278 \text { to } 0.665) \\
<0.0001\end{array}$ & $\begin{array}{l}0.459 \\
(0.302 \text { to } 0.698) \\
<0.0001\end{array}$ & $\begin{array}{l}0.548 \\
(0.363 \text { to } 0.828) \\
0.0004\end{array}$ & $\begin{array}{l}0.438 \\
(0.284 \text { to } 0.676) \\
<0.0001\end{array}$ \\
\hline $\begin{array}{l}\text { Two consecutive year } \\
\text { remission }\end{array}$ & $\begin{array}{l}0.858 \\
(0.566 \text { to } 1.300) \\
0.471\end{array}$ & $\begin{array}{l}0.560 \\
(0.396 \text { to } 0.793) \\
0.0001\end{array}$ & $\begin{array}{l}0.454 \\
(0.319 \text { to } 0.647) \\
<0.0001\end{array}$ & $\begin{array}{l}0.495 \\
(0.341 \text { to } 0.718) \\
<0.0001\end{array}$ & $\begin{array}{l}0.514 \\
(0.359 \text { to } 0.737) \\
<0.0001\end{array}$ & $\begin{array}{l}0.497 \\
(0.345 \text { to } 0.717) \\
<0.0001\end{array}$ & $\begin{array}{l}0.479 \\
(0.327 \text { to } 0.702) \\
<0.0001\end{array}$ \\
\hline 1-year remission & $\begin{array}{l}0.952 \\
(0.611 \text { to } 1.484) \\
0.828\end{array}$ & $\begin{array}{l}0.808 \\
(0.590 \text { to } 1.107) \\
0.185\end{array}$ & $\begin{array}{l}0.766 \\
(0.548 \text { to } 1.071) \\
0.119\end{array}$ & $\begin{array}{l}0.764 \\
(0.554 \text { to } 1.053) \\
0.101\end{array}$ & $\begin{array}{l}0.857 \\
(0.629 \text { to } 1.166) \\
0.326\end{array}$ & $\begin{array}{l}0.888 \\
(0.642 \text { to } 1.227) \\
0.471\end{array}$ & $\begin{array}{l}0.800 \\
(0.583 \text { to } 1.098) \\
0.167\end{array}$ \\
\hline AIC & 1132.83 & 1100.62 & 1082.90 & 1105.87 & 1103.96 & 1101.13 & 1106.59 \\
\hline $\mathrm{BIC}$ & 1159.66 & 1127.44 & 1109.72 & 1132.70 & 1130.78 & 1127.96 & 1133.42 \\
\hline$P$ value & $<0.0001$ & $<0.0001$ & $<0.0001$ & $<0.0001$ & $<0.0001$ & $<0.0001$ & $<0.0001$ \\
\hline
\end{tabular}

Significant variables are given in grey cells.

Number of patients in the analysis: 646.

* SDI increase during follow-up (range 0-4) was considered the dependent variable in Poisson regression. The best performance in predicting damage accrual was identified with the lowest $\mathrm{AIC}$ and $\mathrm{BIC}$.

AIC, Akaike information criterion; BIC, Bayesian information criterion; cSLEDAI, clinical SLE Disease Activity Index 2000; PDN, prednisone; PGA, physician global assessment; SLE, systemic lupus erythematosus.

When PDN $\leq 5 \mathrm{mg} /$ day was combined with PGA $<0.5,57$ $(8.8 \%)$ patients lost 1.4 year/patient in remission.

Among patients with PGA $<0.5$ or $\mathrm{cSLEDAI}=0$, no significant difference in the prevalence, extent and type of damage accrual was observed between patients on PDN $\leq 5 \mathrm{mg} /$ day and those on PDN $>5 \mathrm{mg} /$ day (data not shown).

\section{Damage accrual}

Over the five consecutive year follow-up, 206 (31.9\%) patients developed damage; 280 new damage events were observed, corresponding to 0.43 damage event per 5 years/person.

The prevalence and the extent of damage significantly decreased as the time spent in remission increased with all the definitions (table 4).

In Poisson regression, remission according to $\mathrm{cSLEDAI}=0$ had the best fitness over all other remission models, showing the lowest AIC and BIC (table 4). When PGA was considered (alone or in combination with $c S L E D A I=0$ and/or $P D N \leq 5 \mathrm{mg} /$ day) $\mathrm{AIC}$ and BIC increased, thereby indicating less fitness.

At the Poisson multivariate analysis, remission lasting at least two consecutive years was an independent negative predictor of damage accrual according to all the definitions of remission, except for PDN $\leq 5 \mathrm{mg}$ /day that required at least four consecutive years (table 5); age, vasculitis, high glucocorticoid doses and antiphospholipid antibody syndrome were independent predictors of new damage. Due to the possible impact of Centre variability on PGA evaluation, we performed a Poisson regression analysis adjusted for data source, obtaining similar results (data not shown).

Since the different components of remission definitions might have diverse effects depending on whether continuous or cumulative time periods are considered, we also evaluated the cumulative proportion of follow-up spent in remission during the 5 -year period. By regression analysis, we found that $50 \%$ of the follow-up was the shortest duration of remission which resulted protective against new damage when remission was defined as PGA $<0.5$ or cSLEDAI $=0$, whereas at least $75 \%$ of the follow-up was needed when remission was defined as PDN $\leq 5 \mathrm{mg} /$ day (online supplementary table S2).

When we tested potential definitions of remission that resulted to be protective against damage accrual after at least two consecutive years, we found a similar positive predictive value against damage across all the definitions used (figure 2). In particular, adding PGA $<0.5$ and/or PDN $\leq 5 \mathrm{mg} /$ day to $\mathrm{cSLEDAI}=0 \mathrm{did}$ not improve its positive predictive value, meaning that the ability of $\mathrm{cSLEDAI}=0$ in identifying patients without damage progression is not increased by the concomitant fulfilment of the other items. Addition of PDN $\leq 5 \mathrm{mg} /$ day to $\mathrm{CSLEDAI}=0$ increased the specificity of $c S L E D A I=0$ in predicting no damage accrual while maintaining a higher sensitivity compared with the definitions including PGA $<0.5$ (figure 2 and table 6).

\section{DISCUSSION}

Our aim was to explore the performance of the three major items included in the DORIS definition of remission (cSLEDAI $=0$, PGA $<0.5$ and $\mathrm{PDN} \leq 5 \mathrm{mg} /$ day) in capturing a remission status and in predicting damage accrual.

First, we showed that adding PGA $<0.5$ to $c S L E D A I=0$ led to loss of remission in a relevant proportion of patients, without any significant improvement in its predictive value against damage. Additionally, it did not shorten the time spent in remission required to hinder damage accrual (at least two consecutive years for all remission definitions).

Interestingly, more than one-third of our patients in sustained $\mathrm{cSLEDAI}=0$ spent over 1.7 year with $\mathrm{PGA} \geq 0.5$. These patients had more frequently previous neurological involvement, which may imply difficult attribution of neurological events to SLE activity, ${ }^{18}$ thereby causing discrepancy between cSLEDAI and PGA. They also showed more frequently musculoskeletal involvement yet not classifiable as arthritis according to 
Table 5 Multivariate Poisson regression analysis: predictors of damage accrual over the follow-up (OR, 95\% $\mathrm{Cl}, \mathrm{p}$ value)

\begin{tabular}{|c|c|c|c|c|c|c|c|}
\hline & $\mathrm{PDN} \leq 5 \mathrm{mg} /$ day & PGA $<0.5$ & cSLEDAI $=0$ & $\begin{array}{l}\mathrm{PGA}<0.5 \\
\text { plus PDN } \leq 5 \mathrm{mg} / \text { day }\end{array}$ & $\begin{array}{l}\text { cSLEDAI }=0 \text { plus } \\
\text { PGA }<0.5\end{array}$ & $\begin{array}{l}\text { CSLEDAI=0 plus PDN } \\
\leq 5 \mathrm{mg} / \text { day }\end{array}$ & $\begin{array}{l}\text { CSLEDAl }=0 \text { plus } P G A \\
<0.5 \text { plus PDN } \leq 5 \mathrm{mg} \\
\text { day }\end{array}$ \\
\hline $\begin{array}{l}\text { Five consecutive } \\
\text { year remission }\end{array}$ & $\begin{array}{l}0.498 \\
(0.325 \text { to } 0.762) \\
0.0013\end{array}$ & $\begin{array}{l}0.448 \\
(0.278 \text { to } 0.721) \\
0.001\end{array}$ & $\begin{array}{l}0.467 \\
(0.311 \text { to } 0.702) \\
<0.0001\end{array}$ & $\begin{array}{l}0.431 \\
(0.264 \text { to } 0.705) \\
0.001\end{array}$ & $\begin{array}{l}0.470 \\
(0.292 \text { to } 0.757) \\
0.002\end{array}$ & $\begin{array}{l}0.499 \\
(0.325 \text { to } 0.767) \\
0.002\end{array}$ & $\begin{array}{l}0.442 \\
(0.270 \text { to } 0.722) \\
0.001\end{array}$ \\
\hline $\begin{array}{l}\text { Four consecutive } \\
\text { year remission }\end{array}$ & $\begin{array}{l}0.534 \\
(0.325 \text { to } 0.877) \\
0.013\end{array}$ & $\begin{array}{l}0.322 \\
(0.183 \text { to } 0.567) \\
<0.0001\end{array}$ & $\begin{array}{l}0.230 \\
(0.138 \text { to } 0.385) \\
<0.0001\end{array}$ & $\begin{array}{l}0.400 \\
(0.238 \text { to } 0.670) \\
0.001\end{array}$ & $\begin{array}{l}0.338 \\
(0.192 \text { to } 0.596) \\
<0.0001\end{array}$ & $\begin{array}{l}0.305 \\
(0.186 \text { to } 0.500) \\
<0.0001\end{array}$ & $\begin{array}{l}0.389 \\
(0.229 \text { to } 0.661) \\
<0.0001\end{array}$ \\
\hline $\begin{array}{l}\text { Three consecutive } \\
\text { year remission }\end{array}$ & $\begin{array}{l}0.885 \\
(0.567 \text { to } 1.382) \\
0.59\end{array}$ & $\begin{array}{l}0.500 \\
(0.328 \text { to } 0.764) \\
0.001\end{array}$ & $\begin{array}{l}0.595 \\
(0.393 \text { to } 0.900) \\
0.014\end{array}$ & $\begin{array}{l}0.485 \\
(0.313 \text { to } 0.754) \\
0.001\end{array}$ & $\begin{array}{l}0.527 \\
(0.345 \text { to } 0.805) \\
0.003\end{array}$ & $\begin{array}{l}0.590 \\
(0.387 \text { to } 0.899) \\
0.0014\end{array}$ & $\begin{array}{l}0.490 \\
(0.315 \text { to } 0.760) \\
0.0019\end{array}$ \\
\hline $\begin{array}{l}\text { Two consecutive } \\
\text { year remission }\end{array}$ & $\begin{array}{l}0.878 \\
(0.562 \text { to } 1.370) \\
0.56\end{array}$ & $\begin{array}{l}0.631 \\
(0.444 \text { to } 0.896) \\
0.010\end{array}$ & $\begin{array}{l}0.531 \\
(0.371 \text { to } 0.759) \\
0.001\end{array}$ & $\begin{array}{l}0.554 \\
(0.381 \text { to } 0.805) \\
0.002\end{array}$ & $\begin{array}{l}0.574 \\
(0.400 \text { to } 0.826) \\
0.003\end{array}$ & $\begin{array}{l}0.543 \\
(0.376 \text { to } 0.785) \\
0.001\end{array}$ & $\begin{array}{l}0.532 \\
(0.363 \text { to } 0.781) \\
0.001\end{array}$ \\
\hline 1-year remission & $\begin{array}{l}1.022 \\
(0.642 \text { to } 1.627) \\
0.92\end{array}$ & $\begin{array}{l}0.868 \\
(0.632 \text { to } 1.194) \\
0.386\end{array}$ & $\begin{array}{l}0.915 \\
(0.652 \text { to } 1.284) \\
0.606\end{array}$ & $\begin{array}{l}0.845 \\
(0.610 \text { to } 1.171) \\
0.313\end{array}$ & $\begin{array}{l}0.913 \\
(0.668 \text { to } 1.248) \\
0.566\end{array}$ & $\begin{array}{l}1.072 \\
(0.770 \text { to } 1.494) \\
0.679\end{array}$ & $\begin{array}{l}0.877 \\
(0.636 \text { to } 1.208) \\
0.422\end{array}$ \\
\hline Age at baseline & $\begin{array}{l}1.031 \\
(1.019 \text { to } 1.042) \\
<0.001\end{array}$ & $\begin{array}{l}1.029 \\
(1.017 \text { to } 1.040) \\
<0.001\end{array}$ & $\begin{array}{l}1.032 \\
(1.021 \text { to } 1.044) \\
<0.001\end{array}$ & $\begin{array}{l}1.029 \\
(1.017 \text { to } 1.041) \\
<0.001\end{array}$ & $\begin{array}{l}1.029 \\
(1.017 \text { to } 1.041) \\
<0.0001\end{array}$ & $\begin{array}{l}1.033 \\
(1.033 \text { to } 1.045) \\
<0.001\end{array}$ & $\begin{array}{l}1.029 \\
(1.018 \text { to } 1.041) \\
<0.001\end{array}$ \\
\hline Previous GC pulses & ns & $\begin{array}{l}1.441 \\
(1.100 \text { to } 1.888) \\
0.008\end{array}$ & $\begin{array}{l}1.369 \\
(1.044 \text { to } 1.795) \\
0.023\end{array}$ & $\begin{array}{l}1.452 \\
(1.109 \text { to } 1.901) \\
0.007\end{array}$ & $\begin{array}{l}1.447 \\
(1.105 \text { to } 1.895) \\
0.007\end{array}$ & $\begin{array}{l}1.457 \\
(1.112 \text { to } 1.908) \\
<0.006\end{array}$ & $\begin{array}{l}1.463 \\
\text { (1.117 to } 1.915) \\
0.006\end{array}$ \\
\hline Previous vasculitis & ns & $\begin{array}{l}1.660 \\
(1.175 \text { to } 2.346) \\
0.004\end{array}$ & $\begin{array}{l}1.689 \\
(1.195 \text { to } 2.387) \\
0.003\end{array}$ & $\begin{array}{l}1.656 \\
\text { (1.171 to } 2.341) \\
0.004\end{array}$ & $\begin{array}{l}1.677 \\
(1.187 \text { to } 2.370) \\
0.003\end{array}$ & $\begin{array}{l}1.666 \\
(1.181 \text { to } 2.350) \\
<0.004\end{array}$ & $\begin{array}{l}1.666 \\
(1.179 \text { to } 2.355) \\
0.004\end{array}$ \\
\hline $\begin{array}{l}\text { Cumulative GC dose } \\
\text { at baseline }\end{array}$ & $\begin{array}{l}1.008 \\
(1.001 \text { to } 1.016) \\
0.025\end{array}$ & ns & $\begin{array}{l}1.008 \\
(1.000 \text { to } 1.015) \\
0.036\end{array}$ & $\begin{array}{l}1.007 \\
(1.000 \text { to } 1.014) \\
0.043\end{array}$ & ns & $\begin{array}{l}1.008 \\
(1.001 \text { to } 1.015) \\
0.023\end{array}$ & $\begin{array}{l}1.007 \\
(1.000 \text { to } 1.042) \\
0.046\end{array}$ \\
\hline aPL syndrome & $\begin{array}{l}1.377 \\
(1.008 \text { to } 1.882) \\
0.044\end{array}$ & ns & $\begin{array}{l}1.383 \\
(1.016 \text { to } 1.882) \\
0.039\end{array}$ & ns & ns & ns & ns \\
\hline AIC & 1033.68 & 1031.74 & 1014.99 & 1032.56 & 1032.52 & 1020.78 & 1031.48 \\
\hline $\mathrm{BIC}$ & 1136.52 & 1107.74 & 1090.01 & 1108.56 & 1108.52 & 1096.79 & 1107.49 \\
\hline alue & $<0.0001$ & 0.0001 & 0.0001 & $<0.0001$ & $<0.0001$ & $<0.0001$ & $<0.0001$ \\
\hline
\end{tabular}

Variables with a $\mathrm{p}<0.2$ at the univariate analysis were entered in the multivariate analysis: duration of remission (categorical variable with six levels) and the following characteristics: sex, age, disease duration, baseline SDI, cumulative GC dose at baseline, previous GC pulses, previous cyclophosphamide treatment, previous neurological and renal involvement, previous vasculitis, antiphospholipid syndrome. cSLEDAI, clinical SLE Disease Activity Index 2000. Significant variables are given in grey cells. The table reports only variables with at least one $p<0.05$ at the multivariate analysis for at least one remission definition.

Goodness-of-fit of different models according to the seven definitions of remission are also reported.

AIC, Akaike Information Criterion; aPL, antiphospholipid antibody; BIC, Bayesian Information Criterion; GC, glucocorticoid; ns, not significant; PDN, prednisone-equivalent; PGA, physician global assessment; SDI, Systemic Lupus International Collaborating Clinics/American College of Rheumatology Damage Index.

SLEDAI, leading to higher PDN intake. It should be noted that non specific symptoms (i.e., arthralgias, stiffness, fatigue) are not considered in cSLEDAI, but can increase the PGA without impacting on damage accrual. PGA has a large interobserver and intraobserver variability because it reflects a complex physicianperceived global evaluation not always related to the real disease activity. ${ }^{19} 20$ Therefore, patients in cSLEDAI $=0$ but PGA $\geq 0.5$ should be carefully evaluated in order to distinguish lupus residual activity from other conditions.

Since additional treatment is not always needed in patients with $\mathrm{cSLEDAI}=0$ despite $\mathrm{PGA} \geq 0.5$, and since these items showed overlapping sensitivity, specificity, positive and negative predictive value against damage accrual (table 6 and figure 2), adding PGA $<0.5$ to $c S L E D A I=0$ could lead to overtreatment in controlled trials as well as in clinical practice when a treatto-target (T2T) approach is adopted. ${ }^{21}$ In fact, T2T should aim at the most reachable target that positively influences patient prognosis. We observed that $\mathrm{cSLEDAI}=0$ was the definition of remission easiest to achieve in real life, being able to predict damage accrual with a consistent degree of accuracy. Noteworthy, $c S L E D A I=0$ alone or in combination with other items conferred a similar protection against damage accrual, provided remission lasted at least 2 years (table 5), therefore, posing a rationale for the use of $\mathrm{cSLEDAI}=0$ in spite of composite indexes. Importantly, cSLEDAI $=0$ was already shown to be a feasible target in the BLISS trials, bearing the highest discriminatory capability in capturing remission compared with the DORIS definition, lupus low disease activity state (LLDAS) and $\mathrm{D} / \mathrm{E}$ in all British Isles Lupus Activity Group (BILAG) domains. ${ }^{22}$ Additionally, cSLEDAI $=0$ had the same performance of the SLE Responder Index-4 (SRI-4) in showing the superiority of belimumab over placebo, while displaying a better correlation with PGA $<0.5$ than SRI-4 or LLDAS. ${ }^{22} 23$ Hence, it could be speculated that adding PGA $<0.5$ could hamper the results of randomised trials aiming at remission, as patients achieving $\mathrm{cSLEDAI}=0$ at 52 weeks can still have PGA $\geq 0.5$ which will not affect their outcome.

Since definitions of low disease activity (LDA) use the same items included in definitions of remission (cSLEDAI/SLEDAI-2K, PGA, PDN) although with less stringent cut-offs, a patient fulfilling remission definition is often fulfilling LDA status as well. ${ }^{17} 2425$ Notably, in this study, we found that around two thirds of patients with $\mathrm{cSLEDAI}=0$ and PGA $\geq 0.5$ were in LDA and/or in remission according to cSLEDAI $=0$ and PDN $\leq 5 \mathrm{mg}$ / day. Since a patient can lose remission definition only due to PGA $\geq 0.5$ while maintaining LDA, adding PGA to definitions including $\mathrm{cSLEDAI}=0$ and/or PDN $\leq 5 \mathrm{mg} /$ day leads to a consistent overlap between the definitions of LDA and remission. 111924 


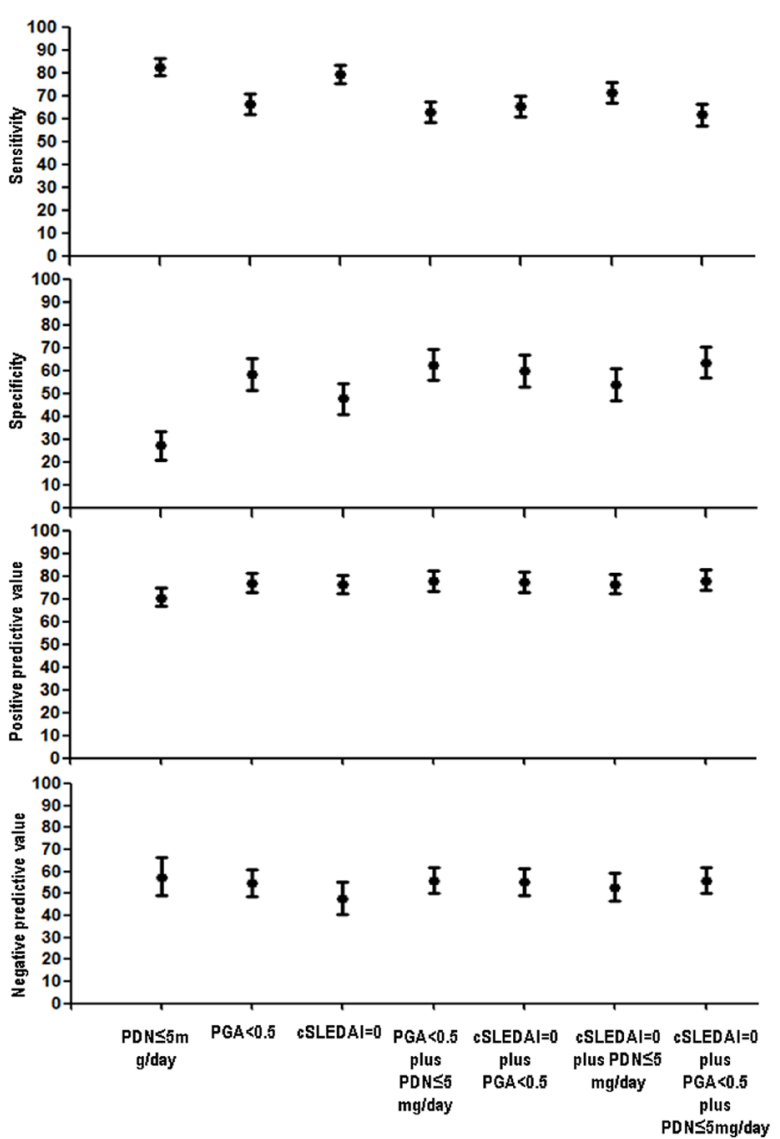

Figure 2 Sensitivity, specificity, positive and negative predictive values of different remission definitions in identifying patients who will not accrue damage throughout the follow-up. Values and their $95 \% \mathrm{Cl}$ are depicted. Remitted is defined as patients with at least two consecutive year remission and unremitted is defined as patients with remission lasting less than 2 years. CSLEDAI, clinical SLE Disease Activity Index; PGA, physician global assessment; PDN, prednisone equivalent; SLE, systemic lupus erythematosus.

On the other hand, 40 out of the 195 patients in $\mathrm{CSLEDAI}=0$ with PGA $\geq 0.5$ did not fulfil LLDAS definition, due to glucocorticoid daily doses and/or PGA over the LLDAS thresholds. This might infer that a significant proportion of patients could have fulfilled simplified remission criteria $(\mathrm{cSLEDAI}=0)$, that is, without lupus manifestations, and still not be in a desirable state of remission, due to a suboptimal HRQoL or to a higher glucocorticoid intake. Nevertheless, patients in $\mathrm{cSLEDAI}=0$ irrespective of PDN dosage and PGA accrued significantly less damage than those with cSLEDAI $>0$ during the follow-up.

A remission lasting at least $50 \%$ of the follow-up was protective against damage accrual in our cohort when remission was defined according to PGA $<0.5$ or $c-S L E D A I=0$. Notably, this duration corresponds to 2.5 cumulative years in our study where the follow-up was 5 years, in keeping with the results of our analysis of continuous-time periods.

We confirmed a good agreement between cSLEDAI $=0$ and PGA $<0.5$ in our real-life cohort. Therefore, a simplified remission definition based on $\mathrm{CSLEDAI}=0$ can be reasonably used in observational studies where complete serological data, PGA and BILAG are not routinely assessed. ${ }^{21}$ In the $c S L E D A I=0$ remission definition, the exclusion of a cut-off for PDN could imply that high dose glucocorticoids may mask disease activity, thus allowing patients not in real remission to be defined as remitted. Nevertheless, we found that adding PDN $\leq 5 \mathrm{mg} /$ day to $\mathrm{cSLEDAI}=0$ does not increase the performance against damage of $\mathrm{cSLEDAI}=0$ in the short/medium term (5 years), as shown by the high overlap between confidence intervals. Of note, the specificity, sensitivity and predictive values of $c S L E D A I=0$ were not significantly improved on addition of other items, with a substantially modest prognostic value of all different definitions of remission in predicting damage-free status (table 6). These observations further support $\mathrm{cSLEDAI}=0$ to be considered the first target to achieve in order to prevent damage accrual, while cSLEDAI $=0$ plus $P D N \leq 5 \mathrm{mg} /$ day could be considered the best target in the medium/long term, since it has been widely demonstrated that even low dose of PDN lead to damage accrual in the longer run. ${ }^{4162627}$

We observed that the majority of patients in remission according to $\mathrm{cSLEDAI}=0$ for at least 1 year were on PDN $\leq 5 \mathrm{mg} /$ day, some being off-steroids (data not shown), while almost half of them were still on immunosuppressive maintenance therapy. This finding reflects the current clinical practice of tapering glucocorticoids before immunosuppressive agents which exert a greater protective effect against flare occurrence in remitted patients. ${ }^{28}$ Accordingly, in a recent study by Mathian et al, ${ }^{29}$ a relevant proportion of remitted patients who discontinued glucocorticoid therapy experienced a flare during 1-year follow-up, but only $26 \%$ of them were on immunosuppressive maintenance therapy at the time of glucocorticoid discontinuation.

There are some limitations in our study that it is a retrospective analysis of prospective collected data, with the majority of patients being Caucasian and follow-up limited to 5 years. Moreover, other relevant outcomes, for example, HRQoL, were not systematically assessed. On the other hand, this is a multicentre real-life

Table 6 Sensitivity, specificity, positive and negative predictive values of different remission definitions in identifying patients without damage accrual throughout the follow-up

\begin{tabular}{|c|c|c|c|c|c|c|c|}
\hline & PDN $\leq 5 \mathrm{mg} /$ day & PGA $<0.5$ & $\mathrm{cSLEDAl}=0$ & $\begin{array}{l}\text { PGA }<0.5 \text { plus PDN } \\
\leq 5 \mathrm{mg} / \text { day }\end{array}$ & $\begin{array}{l}\text { cSLEDAI }=0 \text { plus } \\
\text { PGA }<0.5\end{array}$ & $\begin{array}{l}\text { CSLEDAI }=0 \text { plus PDN } \\
\leq 5 \mathrm{mg} / \text { day }\end{array}$ & $\begin{array}{l}\text { cSLEDAl }=0 \text { plus } P G A \\
<0.5 \text { plus } \text { PDN } \leq 5 \\
\mathrm{mg} / \text { day }\end{array}$ \\
\hline Sensitivity & $\begin{array}{l}82.4 \\
\text { (78.5 to } 85.9)\end{array}$ & $\begin{array}{l}66.2 \\
(61.6 \text { to } 70.6)\end{array}$ & $\begin{array}{l}79.2 \\
(75.1 \text { to } 83.0)\end{array}$ & $\begin{array}{l}62.6 \\
\text { (57.8 to 67.1) }\end{array}$ & $\begin{array}{l}65.1 \\
(60.4 \text { to } 69.5)\end{array}$ & $\begin{array}{l}71.2 \\
(66.8 \text { to } 75.4)\end{array}$ & $\begin{array}{l}61.6 \\
\text { (56.9 to 66.2) }\end{array}$ \\
\hline Specificity & $\begin{array}{l}27.4 \\
(21.5 \text { to } 34.0)\end{array}$ & $\begin{array}{l}58.2 \\
(51.2 \text { to } 65.0)\end{array}$ & $\begin{array}{l}47.6 \\
(40.7 \text { to } 54.6)\end{array}$ & $\begin{array}{l}62.5 \\
\text { (55.5 to 69.1) }\end{array}$ & $\begin{array}{l}59.6 \\
(52.6 \text { to } 66.3)\end{array}$ & $\begin{array}{l}53.9 \\
\text { (46.8 to } 60.8 \text { ) }\end{array}$ & $\begin{array}{l}63.5 \\
(56.5 \text { to } 70.0)\end{array}$ \\
\hline PPV & $\begin{array}{l}70.5 \\
(66.4 \text { to } 74.4)\end{array}$ & $\begin{array}{l}76.9 \\
(72.3 \text { to } 81.1)\end{array}$ & $\begin{array}{l}76.1 \\
\text { (71.9 to } 80.0)\end{array}$ & $\begin{array}{l}77.8 \\
\text { (73.1 to } 82.1)\end{array}$ & $\begin{array}{l}77.2 \\
(72.6 \text { to } 81.4)\end{array}$ & $\begin{array}{l}76.5 \\
(72.1 \text { to } 80.5)\end{array}$ & $\begin{array}{l}78.0 \\
(73.3 \text { to } 82.3)\end{array}$ \\
\hline NPV & $\begin{array}{l}57.5 \\
\text { (48.6 to } 66.0)\end{array}$ & $\begin{array}{l}55.0 \\
(48.9 \text { to } 61.1)\end{array}$ & $\begin{array}{l}47.9 \\
(40.6 \text { to } 55.3)\end{array}$ & $\begin{array}{l}55.8 \\
\text { (49.9 to } 61.6)\end{array}$ & $\begin{array}{l}55.2 \\
\text { (49.2 to } 61.2 \text { ) }\end{array}$ & $\begin{array}{l}52.9 \\
(46.4 \text { to } 59.4)\end{array}$ & $\begin{array}{l}56.0 \\
(50.2 \text { to } 61.7)\end{array}$ \\
\hline
\end{tabular}

Values and their $95 \% \mathrm{Cl}$ are reported.

cSLEDAI, clinical SLE Disease Activity Index; NPV, negative predictive value; PDN, prednisone-equivalent; PGA, physician global assessment; PPV, positive predictive value; SLE, systemic lupus erythematosus. 
observational cohort where patients were closely followed-up and homogeneously treated according to current recommendations.

In conclusion, $\mathrm{cSLEDAI}=0$ was the most achievable definition of remission and showed a good performance in terms of damage prediction, while addition of PGA $<0.5$ to $c$ SLEDAI $=0$ was not relevant in identifying patients who would develop damage, thus submitting cSLEDAI $=0$ as the most advisable target in a short-tomid-term follow-up.

\section{Author affiliations}

'Department of Medicine, Division of Rheumatology, University of Padua, Padova, Italy

'Unit of Allergology, Immunolgy, Rheumatology, Department of Medicine, Universita Campus Bio-Medico di Roma, Roma, Italy

${ }^{3}$ Dipartimento di Medicina Interna e Specialità Mediche, Reumatologia, Sapienza University of Rome, Roma, Lazio, Italy

${ }^{4}$ Department of Clinical, Internal, Anesthesiological and Cardiovascular Sciences, Rheumatology Unit, Sapienza University of Rome, Roma, Lazio, Italy

${ }^{5}$ University Hospital Arcispedale Sant'Anna, Department of Medical Sciences, Division of Rheumatology, University of Ferrara, Ferrara, Emilia-Romagna, Italy

${ }^{6}$ Nephrology Unit, La Fondazione IRCCS Ca' Granda Ospedale Maggiore di Milano Policlinico, Milano, Lombardia, Italy

${ }^{7}$ ASST-Spedali Civili, Rheumatology and Clinical Immunology, University of Brescia, Brescia, Lombardia, Italy

${ }^{8}$ Department of Clinical and Experimental Medicine, Rheumatology Unit, University of Pisa, Pisa, Toscana, Italy

${ }^{9}$ Department of Cardiac-Thoracic-Vascular Sciences and Public Health, Biostatistics, Epidemiology and Public Health Unit, University of Padua, Padova, Veneto, Italy

Contributors FS contributed to the conception and design of the work, the follow-up of patients, acquisition, analysis and interpretation of data, and mostly drafted the work; MZ and MGa followed up patients, contributed to the acquisition of data and helped in drafting and revising the paper; $F C 0, A A, G M, M G o, A T, M M$ and LI followed up patients and revised the manuscript; FCe, DPEM, GF, FD, VS and $A B$ followed up patients and contributed to the acquisition of data; $A C F$ contributed to and revised the analysis of data; $A D$ designed the work, interpreted the data and revised the manuscript for important intellectual content. All the authors approved the final version of the manuscript and gave their agreement to be accountable for all aspects of the work in ensuring that questions related to the accuracy or integrity of any part of the work are appropriately investigated and resolved.

Funding The authors have not declared a specific grant for this research from any funding agency in the public, commercial or not-for-profit sectors.

\section{Competing interests None declared.}

Patient and public involvement Patients and/or the public were not involved in the design, or conduct, or reporting, or dissemination plans of this research.

Patient consent for publication Not required.

Ethics approval The study was approved by the Ethics committee of Padova University (3806/A016)

Provenance and peer review Not commissioned; externally peer reviewed.

Data availability statement All data relevant to the study are included in the article or uploaded as online supplementary information. Data are available on reasonable request from Prof A Doria (ORCID 0000-0003-0548-4983). Reuse of data is not permitted by a third party without authorisation.

\section{ORCID iDs}

Fulvia Ceccarelli http://orcid.org/0000-0001-5026-8783

Gabriella Moroni http://orcid.org/0000-0003-3256-476X

Andrea Doria http://orcid.org/0000-0003-0548-4983

\section{REFERENCES}

1 van Vollenhoven RF, Mosca M, Bertsias G, et al. Treat-to-target in systemic lupus erythematosus: recommendations from an international Task force. Ann Rheum Dis 2014;73:958-67.

2 Fanouriakis A, Kostopoulou M, Alunno A, et al. 2019 update of the EULAR recommendations for the management of systemic lupus erythematosus. Ann Rheum Dis 2019;78:736-45.

3 Zen M, laccarino L, Gatto M, et al. Prolonged remission in Caucasian patients with SLE: prevalence and outcomes. Ann Rheum Dis 2015;74:2117-22.
4 Zen $M$, laccarino L, Gatto M, et al. The effect of different durations of remission on damage accrual: results from a prospective monocentric cohort of Caucasian patients. Ann Rheum Dis 2017;76:562-5.

5 Moroni G, Quaglini S, Gallelli B, et al. The long-term outcome of 93 patients with proliferative lupus nephritis. Nephrol Dial Transplant 2007;22:2531-9.

6 Steiman AJ, Gladman DD, Ibañez D, et al. Outcomes in patients with systemic lupus erythematosus with and without a prolonged serologically active clinically quiescent period. Arthritis Care Res 2012;64:511-8.

7 Mok CC, Ho LY, Tse SM, et al. Prevalence of remission and its effect on damage and quality of life in Chinese patients with systemic lupus erythematosus. Ann Rheum Dis 2017;76:1420-5

8 Petri M, Magder LS. Comparison of remission and lupus low disease activity state in damage prevention in a United States systemic lupus erythematosus cohort. Arthritis Rheumatol 2018;70:1790-5.

9 Tselios K, Gladman DD, Touma Z, et al. Disease course patterns in systemic lupus erythematosus. Lupus 2019;28:114-22.

10 van Vollenhoven R, Voskuyl A, Bertsias G, et al. A framework for remission in SLE: consensus findings from a large international Task force on definitions of remission in SLE (DORIS). Ann Rheum Dis 2017:76:554-61.

11 Tselios K, Gladman DD, Urowitz MB. How can we define low disease activity in systemic lupus erythematosus? Semin Arthritis Rheum 2019;48:1035-40.

12 Castrejón I, Tani C, Jolly M, et al. Indices to assess patients with systemic lupus erythematosus in clinical trials, long-term observational studies, and clinical care. Clin Exp Rheumatol 2014;32:S-85-95.

13 Polachek A, Gladman DD, Su J, et al. Defining low disease activity in systemic lupus erythematosus. Arthritis Care Res 2017;69:997-1003.

14 Ugarte-Gil MF, Wojdyla D, Pons-Estel GJ, et al. Remission and low disease activity status (LDAS) protect lupus patients from damage occurrence: data from a multiethnic, multinational Latin American lupus cohort (GLADEL). Ann Rheum Dis 2017:76:2071-4.

15 Petri M, Buyon J, Kim M. Classification and definition of major flares in SLE clinical trials. Lupus 1999;8:685-91.

16 Gladman DD, Urowitz MB, Rahman P, et al. Accrual of organ damage over time in patients with systemic lupus erythematosus. J Rheumatol 2003;30:1955-9.

17 Franklyn K, Lau CS, Navarra SV, et al. Definition and initial validation of a lupus low disease activity state (LLDAS). Ann Rheum Dis 2016;75:1615-21.

18 Govoni M, Bombardieri S, Bortoluzzi A, et al. Factors and comorbidities associated with first neuropsychiatric event in systemic lupus erythematosus: does a risk profile exist? a large multicentre retrospective cross-sectional study on 959 Italian patients. Rheumatology 2012:51:157-68.

19 Wollaston SJ, Farewell VT, Isenberg DA, et al. Defining response in systemic lupus erythematosus: a study by the systemic lupus international collaborating clinics group. J Rheumatol 2004;31:2390-4.

20 Petri M, Kawata AK, Fernandes AW, et al. Impaired health status and the effect of pain and fatigue on functioning in clinical trial patients with systemic lupus erythematosus. J Rheumatol 2013:40:1865-74.

21 Gatto M, Saccon F, Zen M, et al. Early disease and low baseline damage predict response to belimumab in patients with systemic lupus erythematosus. Arthritis Rheumatol 2020.

22 Parodis I, Emamikia S, Gomez A, et al. Definitions of remission in systemic lupus erythematosus: a post-hoc analysis of two randomised clinical trials. Lancet Rheumatol 2019;1:e163-73.

23 Parodis I, Emamikia S, Gomez A, et al. Clinical SLEDAI-2K zero may be a pragmatic outcome measure in SLE studies. Expert Opin Biol Ther 2019;19:157-68.

24 Tselios K, Gladman DD, Touma Z, et al. Clinical remission and low disease activity outcomes over 10 years in systemic lupus erythematosus. Arthritis Care Res 2019:71:822-8

25 Zen $\mathrm{M}$, laccarino L, Gatto $\mathrm{M}$, et al. Lupus low disease activity state is associated with a decrease in damage progression in Caucasian patients with SLE, but overlaps with remission. Ann Rheum Dis 2018;77:104-10.

26 Thamer M, Hernán MA, Zhang Y, et al. Prednisone, lupus activity, and permanent organ damage. J Rheumatol 2009;36:560-4.

27 Magder LS, Petri M. Incidence of and risk factors for adverse cardiovascular events among patients with systemic lupus erythematosus. Am J Epidemiol 2012;176:708-19.

28 Zen M, Saccon F, Gatto M, et al. Prevalence and predictors of flare after immunosuppressant discontinuation in patients with systemic lupus erythematosus in remission. Rheumatology 2019. doi:10.1093/rheumatology/kez422. [Epub ahead of print: 23 Oct 2019].

29 Mathian A, Pha M, Haroche J, et al. Withdrawal of low-dose prednisone in SLE patients with a clinically quiescent disease for more than 1 year: a randomised clinical trial. Ann Rheum Dis 2020;79:339-46. 